\title{
Biomorph Limosella aquatica $L$. and its contribution in stolon-rosette water grasses formation
}

\author{
Natalya Savinykh ${ }^{1 *}$, and Marya Shakleina ${ }^{2}$ \\ ${ }^{1}$ Centre competence "Usage of biological resources" of the Vyatka State University, 610000, Kirov, \\ Russia \\ ${ }^{2}$ Department of Biology and Methods of Biology Teaching, the Vyatka State University, 610000, \\ Kirov, Russia
}

\begin{abstract}
The paper presents comparative-morphological analysis of biomorphs Limosella aquatica L., stolon-rosette perennial mesophyte grasses (Viola odorata L.), and yearling vegetative hydrophytes (Stratiotes aloides L. and Hydrocharis morsus-ranae L.). It is shown that L. aquatica is a monopodial growing monocarpic with side stolon-rosette shoots and their systems with up to four branching orders. The primary shoot, as well as rosette parts of stolon-rosette shoots, is made of metamers with foliage leafs, axil complexes with differently sets of constituents: two collateral buds and/or their derivatives: flower buds/flowers/fruit, side stolon-rosette shoots or their systems. At the initial stage the shoot-forming mode of $L$. aquatica is similar to that of $V$. odorata: a monopodial rosette one with green assimilating leaves, flowers, and stolon-rosette shoots. But iterative branching of stolon-rosette shoots changes the shoot-forming mode of L. aquatica to a sympodial semirosette as in S. aloides, and especially in $H$. morsus-ranae. Biomorph $L$. aquatica combines the features of stolonrosette perennial mesophyte grasses and stolon-rosette yearling vegetative hydrophytes: stolon-rosette shoot formation from axil buds, iterative branching, collateral buds, reduction inflorescence to one flower (S. aloides). Thus of habit L. aquatica can be viewed as a stage of perennial flower mesophyte plants' shifting to life in water.
\end{abstract}

\section{Introduction}

The model of shoot-forming as a process of forming shoot systems in ontogenesis is adaptable and genetically predetermined. It is formed in course of evolution as plants' adaptation to environmental conditions. Therefore shoot systems of many non-related plants are built by the same algorithm. T. I. Serebryakova [1] described 4 models of shootforming. On the basis of each of them [2], in the course of changing individual parts of shoot systems and their repeating elements (elementary metamers) are formed various variants of shoot formation. Quite often the model is changed in course of ontogenesis. One

\footnotetext{
*Corresponding author: savva 09@mail.ru
} 
of the most variable among them is the monopodial rosette, what is successfully illustrated by T. I. Serebryakova [3].

Plants of this model are met in conditions of changing (aggradation) the moistening level. For example, a perennial mesophyte Viola odorata L. has a typical monopodial rosette model, but formation of upper-rosette shoots in course of ontogenesis makes the biomorph change from a monocentric one to a polycentric one, and the plant becomes a vegetative-mobile one [4]. Typical hydrophytes, yearling plants with vegetative origin Stratiotes aloides L., have the model of shoot-forming which is close to a monopodial rosette one with the same change of the biomorph, while the model of Hydrocharis morsusranae L. is a typical sympodial upper-rosette one [5]. In conditions of variable moistening, on the beach and foreshore of water grows a stolon-rosette yearling hygrophyte Limosella aquatica $\mathrm{L}$. which has the same model of shoot-forming and the same change of biomorph in ontogenesis.

Thus the aim of this research is to access the role and place of the biomorph L. aquatica as a structural-functional complex in the origin of stolon-rosette water grasses in the secondary repopulating of water bodies by flowering plants.

\section{Materials and methods}

The object of research is represented by L. aquatica, it is a circumboreal, arctic-moderatetropical [6], plurizonal [7] species; a hygrophyte [7]. The area of the species includes Arctic, Scandinavia, Middle and Atlantic Europe, India, the Himalayas, Mongolia, Japan, China (Manchuria), North and South America, Australia, and Africa [8]. Its main habitats are mud or sandy banks, shallows, drying of the bottoms of water bodies, ditches, pools, floodplain and turfy meadows [8].

The research was carried out in June-September 2019 in the communities of sandy banks of the right bank of the Vyatka River in the vicinity of Kirov. Shoot systems of L. aquatica were extracted from the substrate. Their structure was carefully considered in the laboratory with the help of a stereoscopic microscope MSP-1 variant 22 . The structures were photographed with the videoocular ToupCam 9.0. The structure schematics of shoot systems were made with the use of the software Adobe Illustrator CS6. The life form of L. aquatica described based on representations of I. G. Serebryakov [9-11] and C. Raunkiaer [12], also the research of M. V. Markov was taken into account [13, 14]. The model of shoot-forming was determined according to T. I. Serebryakova [2, 3].

For the comparative analysis of biomorphs, the data of T. I. Serebryakova and T. V. Bogomolova in biomorphology of V. odorata [4] and the data of D. Yu. Petukhova on $S$. aloides and $H$. morsus-ranae [5].

\section{Results}

L. aquatica is a yearling grass plant 5-7 sm high with a secondary-homorizal root system. On to I. G. Serebryakov [11], it is a yearling protractedly-vegetating monocarpic grass plant with assimilating shoots of a non-succulent type not needing any prop. M. V. Markov in one of his latest works [14] describes the species as a heteromodule homorizal amphibious short-lived plant with a rhythmical alternation of short internodes (rosettes) and long internodes (stolons). From the position the model of shoot-forming, it is a monopodialgrowing rosette monocarpic plant with side stolon-upper-rosette shoots and their systems with up to four branching orders (fig.). One plant can have up to 14 such a shoots and systems. 
The primary rosette shoot consists of 15-20 metameres with foliage leaves. The leaves are a bit succulent, without stipules, mocropodous, simple, from 6.9 to $16.5(10.86 \pm 2.98)$ sm long. The lamina is $2.8-5.8(4.13 \pm 0.86) \mathrm{sm}$ long, and $0.6-1.2(0.99 \pm 0.19) \mathrm{sm}$ wide, it is smooth-edged, elliptical with a rounded leaf tip and a cuniform fan. In the leaf axils there are collateral buts and their derivatives: flower buds, flowers, fruit, side stolon-rosette shoots and their systems. A high speed of ontogenesis is characteristic of this plant: in the laboratory already the germinants develop caulogenous additional roots in the lower part of the hypocotyls and a flower with a bud in the axil of the first leaf. It causes formation of neotenic forms, generative plants with a juvenile habit [13]. In natural conditions plants' development is several slowed, thus virginile ontogenetic state can be pointed out in their ontogenesis [13].

Stolon-rosette shoots differ in the number of metameres (1 or 2) of the basal part with long internodes (fig.). Axil complexes of rosette patches (including those at the tops of side stolon-rosette shoots) are represented in the following combinations: a flower bud/flower and a bud; a flower/fruit and a side stolon-rosette shoot; two side stolon-rosette shoots; a fruit and a system of side stolon-rosette shoots with successive (up to 4) branching orders (fig.). Shoot systems are being formed continuously, so shoot systems in the base of the primary rosette shoot are branched in a greater degree. So it is provides conditions for iterative branching (continuous formation during a vegetative period of several consistently branching shoots forming the axis of the plant), which is typical of grasses in conditions of increased moistening, especially for hygrophytes and hydrophytes. Axil complexes formation increases the area of the assimilating surface, energy of seed reproduction of the plants, prolonged asynchronical fruitage and active expansion.

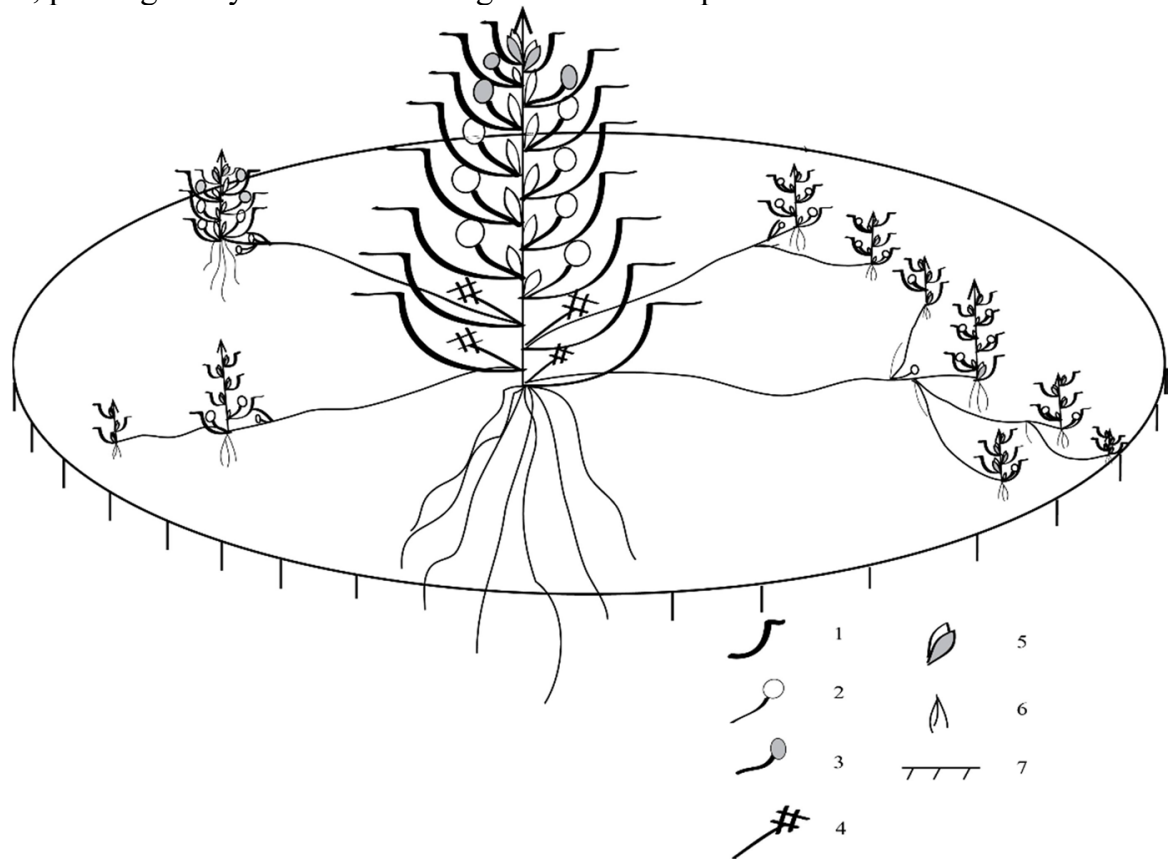

Fig. The scheme of Limosella aquatica shoot system structure (only variations of axil complexes structure are shown, internodes of rosette parts of the shoots are drawn apart): 1 - a middle formation leaf; 2 - flower; 3 - flower bud; 4 - fruit; 5 - collateral buds; 6 - additional roots; 7 - ground line.

By of rooting of stolon-rosetter shoots and formation of a polycentric ontobiomorph internodes do not decay, the link with the n-ordered shoots remains up to the moment of death of the whole plant. As a result, the area of soil nutrition expands, which is very 
important in case of increased dryness after the fall of the flood at the banks of water bodies.

\section{Discussion}

5 features of shoot systems of the model species are considered (table).

Table. Comparative characteristics of the model specie

\begin{tabular}{|c|l|l|l|l|l|}
\hline № & \multicolumn{1}{|c|}{ Feature } & Viola odorata & $\begin{array}{c}\text { Limosella } \\
\text { aquatica }\end{array}$ & $\begin{array}{c}\text { Stratiotes } \\
\text { aloides }\end{array}$ & $\begin{array}{c}\text { Hydrocharis } \\
\text { morsus-ranae }\end{array}$ \\
\hline 1 & Rosette patch growth & Monopodial & Monopodial & Monopodial & Sympodial \\
\hline 2 & Iterative branching & No & Yes & Yes & Yes \\
\hline 3 & $\begin{array}{l}\text { The number of } \\
\text { metameres with long } \\
\text { internodes }\end{array}$ & more than 2 & $1-2$ & 1 & 1 \\
\hline 4 & Fragmentation & $\begin{array}{l}\text { Normal full } \\
\text { specialized }\end{array}$ & $\begin{array}{l}\text { Does not take } \\
\text { place }\end{array}$ & $\begin{array}{l}\text { Early full } \\
\text { specialized }\end{array}$ & $\begin{array}{l}\text { Early full } \\
\text { specialized }\end{array}$ \\
\hline 5 & $\begin{array}{l}\text { Specialized organs of } \\
\text { vegetative propagation }\end{array}$ & No & No & Turions & Turions \\
\hline
\end{tabular}

Evidently, all the model species are characterized by monopodial growth of rosette patch, except $H$. morsus-ranae with sympodial axis growth. Iterative branching is typical for all the species except $V$. odorata. This characteristic feature of shoot formation can be considered as abbreviation of the bud phase in development of a shoot substitute; lengthening of an internode / internodes could be viewed as prolongation that provides the expansion and establishment individual (together with rootage at the phase forming a rosette part of a side shoot). A perennial polycarpous mesophyte is characterized by normal full fragmentation; a monocarpous hygrophyte has no fragmentation; a yearling hydrophyte of a vegetative origin is characterized by early full fragmentation. Only hydrophytes have specialized organs of vegetative propagation: H. morsus-ranae has typical turions which develop at the ends of stolons and at the top of the upper-rosette shoot in late summer; S. aloides has both separate daughter formations (rosettes) and turions from a small prolonged internode and a top bud, they overwinter in leaf axils of daughter rosettes after inserting on the bottom of a water body in autumn. L. aquatica has accessory buds in an axil complex of all the leaves of a rosette shoots. They strengthen the reproductive effort of a plant and its seed propagation. Vegetative propagation typical of hydrophytes does not take place here.

\section{Conclusion}

The biomorph $L$. aquatica combines the feature of rosette perennial mesophyte grasses, such as development of side stolon-rosette shoots ( $V$. odorata) [4] and of stolon-rosette yearling vegetative hydrophytes, such as forming stolon-rosette shoots from axil buds without the dormant period, iterative branching, collateral buds, reduction inflorescence to one flower (female $S$. aloides) [5]. Appearing of this type of mien, a monopodially growing monocarpous with side stolon-rosette shoots and their systems, can be considered as a critical stage of perennial mesophyte grasses transferring to life in water during the secondary colonization expansion of water bodies with flowering plants. Radiocarbon analysis showed that the age of L. aquatica from West Norway is 10000-9465 years old; it goes back to early Holocene [15]. This biomorph still has an architectural appearance of a perennial stolon-rosette-developing vegetatively mobile mesophyte, but it already has 
iterative branching and axil complexes in conditions of high humidity. It is a preadaptation, in case of its progressing with further morphological disintegration and developing its vegetative diasporas, a shift to the life of hydrophytes as stolon-rosette polycarpics yearling of vegetative origin is possible.

\section{References}

1. T. I. Serebryakova, Bull. of Moscow Society of Naturalists. Biological ser., 82 (1977)

2. T. I. Serebryakova, Life forms: structure, spectra, evolution, (Science, Moscow, 1981)

3. T. I. Serebryakova, On variants of shoots formation models in perennial grasses, in Morphogenesis and rhythm of development of higher plants: Intercollegiate collection of scientific papers, MSPI named afer V. I. Lenin, Moscow, Russia (1987)

4. T. I. Serebryakova, T. V. Bogomolova, Bot. j., 69 (1984)

5. D. Yu. Petukhova, Biomorphology of stolon-rosette hydrophytes (Syktyvkar, 2008)

6. N. N. Tsvelev, Manual of vascular plants in North-Western Russia (Publ. of the St. Petersburg State Chemical-Pharmaceutical Academy, St. Petersburg, 2000)

7. V. G. Papchenkov, Vegetation cover of water reservoirs and water courses of the Middle Volga region (International University of Business and New Technologies, Yaroslavl, 2001)

8. S. G. Gorshkova, Flora of the USSR (Moscow, 1955)

9. I. G. Serebryakov, Bull. of Moscow Society of Naturalists. Biological ser., 60, 3 (1955)

10. I. G. Serebryakov, Ecological morphology of plants (life forms of angiosperms and conifers) (Higher School, Moscow, 1962)

11. I. G. Serebryakov, Field geobotany, 3 (1964)

12. C. Raunkiaer, The life forms of plants and statistical plant geography (At the clarendon press, Oxford, 1934)

13. M. V. Markov, Ontogenetic Atlas of plants, 5 (2007)

14. M. V. Markov, Principles and methods of biodiversity conservation (LLC «Vertola», Yoshkar-Ola, 2019)

15. H. H. Birks, J. of Paleolimnology, 23 (2000) 